\title{
Peripheral blood mononuclear cells of breast cancer patients can be reprogrammed to enhance anti-HER-2/neu reactivity and overcome myeloid-derived suppressor cells
}

\author{
Kyle K Payne ${ }^{1 *}$, Christine K Zoon ${ }^{1}$, Wen Wan ${ }^{1}$, Khin Marlar², Rebecca C Keim¹, Mehrab Nasiri Kenari², \\ Latif Kazim², Harry D Bear ${ }^{1}$, Masoud H Manjili ${ }^{1}$
}

From Society for Immunotherapy of Cancer 28th Annual Meeting

National Harbor, MD, USA. 8-10 November 2013

Barriers limiting the efficacy of adoptive cellular therapy (ACT) for breast cancer patients include immune suppression mediated by myeloid-derived suppressor cells (MDSC) and a low frequency of tumor-reactive memory $\mathrm{T}$ cells $(\mathrm{Tm})$. Recently, we developed an ex vivo protocol to reprogram tumor-reactive murine splenocytes; these cells were found to be resistant to MDSC suppression and protected FVBN202 mice from tumor challenge. Here, we evaluated the clinical applicability of reprogramming tumor-sensitized PBMCs isolated from patients with early stage breast cancer by treatment with bryostatin 1 and ionomycin (B/I) combined with IL-2, IL-7 and IL-15. Our data demonstrate that reprogrammed cells are enriched with Tm cells $(\mathrm{n}=5 ; \mathrm{p}=0.006)$, as well as activated $\mathrm{CD}_{5} 6^{+}(\mathrm{n}=6 ; \mathrm{p}=0.003)$ and $\mathrm{CD} 161^{+}(\mathrm{n}=4 ; \mathrm{p}=0.02)$ NKT cells, and demonstrate expansion in total cell numbers $(\mathrm{n}=16 ; \mathrm{p}=0.003)$ compared to baseline cells. Reprogrammed PBMCs displayed enhanced HER-2/ neu-specific IFN- $\gamma$ producing immune responses $(n=6$; $\mathrm{p}=0.04$ ); non-reprogrammed control PBMC IFN- $\gamma$ production was not significant $(\mathrm{n}=6 ; \mathrm{p}=0.4)$. Furthermore, high-throughput sequencing analysis of the $\mathrm{T}$ cell receptor (TcR) V $\beta$ in one patient demonstrated clonal expansion of specific TcR VJ recombination events resulting from cellular reprogramming, suggestive of an enriched frequency of specific tumor antigen-primed $\mathrm{T}$ cell clones. Interestingly, reprogrammed $\mathrm{T}$ cells were resistant to autologous $\mathrm{CD}_{3}{ }^{+} \mathrm{CD} 11 \mathrm{~b}^{+}$HLA-DR ${ }^{10 /-}$ MDSCs, as determined by further enhanced HER-2/ neu-specific IFN- $\gamma$ secretion in the presence of MDSCs $(\mathrm{n}=6 ; \mathrm{p}=0.03)$. Activated $\mathrm{CD} 161^{+} \mathrm{NKT}$ cells comprising $3 \%$ or greater of total reprogrammed cells rendered $\mathrm{T}$ cells resistant to MDSCs $(n=3 ; p=0.02)$. Upregulation of NKG2D expression on $\mathrm{CD}_{161^{+}}(\mathrm{n}=5 ; \mathrm{p}=0.0006)$ and $\mathrm{CD}^{+} 6^{+}(\mathrm{n}=5 ; \mathrm{p}=0.04)$ NKT cells resulted from cellular reprogramming. Therefore, NKG2D signaling was blocked using anti-NKG2D blocking antibody in our co-culture system, resulting in the abrogation of resistance to MDSCs as determined by blunted IFN- $\gamma$ secretion $(n=3 ; p=0.04)$. Finally, the phenotype of MDSCs after co-culture with reprogrammed PBMC was examined; we observed downregulation of $\mathrm{CD} 11 \mathrm{~b}$ expression $(\mathrm{n}=3 ; \mathrm{p}=0.02)$ concomitant with HLA-DR upregulation on MDSCs $(n=3$; $\mathrm{p}=0.001$ ); suggestive of induced maturation of MDSCs into Dendritic Cells (DC). The results of our study offer the following strategies to improve ACT of breast cancer: i) inclusion of activated NKT cells in ACT to overcome MDSC suppression by inducing MDSC maturation into DCs, and ii) PBMC reprogramming to enrich the frequency of tumor-reactive Tm cells. 


\section{Authors' details}

'Virginia Commonwealth University - Massey Cancer Center, Richmond, VA,

USA. ${ }^{2}$ Roswell Park Cancer Institute, Buffalo, NY, USA.

Published: 7 November 2013

doi:10.1186/2051-1426-1-S1-P170

Cite this article as: Payne et al:: Peripheral blood mononuclear cells of breast cancer patients can be reprogrammed to enhance anti-HER-2/ neu reactivity and overcome myeloid-derived suppressor cells. Journal for Immunotherapy of Cancer 2013 1(Suppl 1):P170.

Submit your next manuscript to BioMed Central and take full advantage of:

- Convenient online submission

- Thorough peer review

- No space constraints or color figure charges

- Immediate publication on acceptance

- Inclusion in PubMed, CAS, Scopus and Google Scholar

- Research which is freely available for redistribution

Submit your manuscript at www.biomedcentral.com/submit
Ciomed Central 